\title{
Podophyllotoxin Concentration in Junipers in the Big Horn Mountains in Wyoming
}

\author{
Valtcho D. Zheljazkov ${ }^{1}$ \\ University of Wyoming, Sheridan Research and Extension Center, 663 \\ Wyarno Road, Sheridan, WY 82801
}

Charles L. Cantrell

USDA, Agricultural Research Service, NPURU, University, MS 38677

Mateus Augusto Donega

Escola Superior de Agricultura "Luiz de Queiroz"-Universidade de São Paulo, Av. Pádua Dias, 11-13418-900 Piracicaba, Brazil

Tess Astatkie

Dalhousie University, Faculty of Agriculture, Truro, Nova Scotia, B2N 5E3,
Canada

Bonnie Heidel

University of Wyoming, WY Natural Diversity Database, 1000 E. University Avenue, Laramie, WY 82071

Additional index words. Juniperus horizontalis, Juniperus scopulorum, anticancer

Abstract. Podophyllotoxin is used for the production of the anticancer drugs etoposide, etopophos, and teniposide. Currently, podophyllotoxin is extracted from the Himalayan mayapple (Podophyllum hexandrum Royle). Some junipers and other species also contain the same natural product and have been explored as a domestic source for this compound. The objective of this study was to screen junipers in the Big Horn Mountains in Wyoming for podophyllotoxin. Twenty junipers (18 accessions of Juniperus horizontalis Moench. and two accessions of $J$. scopulorum Sarg.) were sampled in Mar. 2012 and analyzed for podophyllotoxin. Podophyllotoxin concentration in the samples varied from $0.058 \%$ to $0.673 \%$ with five accessions having podophylloxin concentration above $0.5 \%$. This study demonstrated wide variation of podophyllotoxin in $J$. horizontalis and J. scopulorum in the Big Horn Mountains. Some of the accessions had greater than $0.5 \%$ podophyllotoxin making them a feasible source for podophyllotoxin extraction.

Podophyllotoxin is used as a chemical precursor for the production of the anticancer drugs etoposide, etopophos, and teniposide, which are used for the treatment of lung cancer, testicular cancer, neuroblastoma, and hepatoma (Imbert, 1998; Koulman et al., 2004; Stahelin and Wartburg, 1991). In addition, some other derivatives of podophyllotoxin were found to be promising in the treatment

Received for publication 4 Sept. 2012. Accepted for publication 1 Oct. 2012.

This research was funded in part by the University of Wyoming startup funding awarded to Dr. Zheljazkov.

We thank the Forest Service of the U.S. Department of Agriculture for issuing us a permit to sample junipers in the Bighorn National Forest. We thank Mr. Travis Fack, Natural Resource Specialist, and Mr. Clarke McClung, Tongue District Ranger, for helping with the permit. We thank Mr. Lyn Ciampa and Mrs. Ekaterina Jeliazikova for their help with the collections of junipers in the Big Horn Mountains.

${ }^{1}$ To whom reprint requests should be addressed; e-mailvjeliazk@uwyo.edu; valtcho.pubs@gmail. com. of psoriasis, malaria (Leander and Rosen, 1988; Lerndal and Svensson, 2000), and also as antiviral agents (Hammonds et al., 1996). Currently, the only commercial source for podophyllotoxin is the Himalayan mayapple (Podophyllum hexandrum Royle, syn. P. emodi Wall ex. Honigberger), an endangered species in India.

Researchers identified a number of other species that contain podophyllotoxin. Much research has been focused on the American mayapple ( $P$. peltatum L.), a native species in North America. Despite numerous studies on American mayapple in Poland, Russia (Bogdanova and Sokolov, 1973; Saraeva, 1952), and in the United States (Cushman et al., 2005; Meijer, 1974; Moraes et al., 2002; Zheljazkov et al., 2009), this species was not domesticated as a result of its limitations.

Eastern red cedar (Juniperus virginiana) has also been investigated as a source for podophyllotoxin (Canel et al., 2001; Cushman et al., 2003; Gawde et al., 2009; Hartwell et al., 1953). Rocky mountain juniper (J. scopulorum) also contains podophyllotoxin (Cantrell et al., 2013; Renouard et al., 2011) although in lower concentrations than Eastern red cedar. Our preliminary studies in the Big Horn Mountains found that some accessions of creeping juniper (J. horizontalis Moench.) had much greater concentrations of podophyllotoxin than reported for any other juniper species. Therefore, the objective of this study was to screen different accessions of creeping juniper in the Big Horn Mountains and establish the range of podophyllotoxin concentrations.

\section{Materials and Methods}

Plant collection. In Mar. 2012, 20 different junipers (18 accessions of Juniperus horizontalis Moench. and two accessions of J. scopulorum Sarg.) were sampled in the Big Horn Mountains of Wyoming. The sampling area was chosen based on our preliminary studies that found accessions with high podophyllotoxin, and this area is characterized by a very high density of creeping junipers. Samples were taken from naturally occurring junipers situated at least $30 \mathrm{~m}$ away from any roads. From each plant, $\approx 1 \mathrm{~kg}$ of fresh material was collected. Only mature leaves of the juniper plants were sampled. The GPS coordinates were recorded for every plant accession that was sampled. The collected samples were dried in a shady aerated area at temperatures between 22 and $28{ }^{\circ} \mathrm{C}$ until constant weight. Subsamples from each collection were identified by Bonnie Heidel, a botanist at the Wyoming Natural Diversity Database, University of Wyoming, and representative vouchers were deposited in the University of Wyoming Rocky Mountain Herbarium.

Podophyllotoxin. The extraction and purification of podophyllotoxin from the collected juniper samples was as previously described (Canel et al., 2001). Approximately $40 \mathrm{mg}$ of each dry tissue sample was incubated at $20{ }^{\circ} \mathrm{C}$ with $0.6 \mathrm{~mL}$ of $25 \mathrm{~mm}$ potassium phosphate buffer $(\mathrm{pH}$ of 7.0$)$ on an Eppendorf Thermomixer R for $30 \mathrm{~min}$ at $750 \mathrm{rpm}$. Subsequently, $0.6 \mathrm{~mL}$ of ethyl acetate was added, and the incubation continued for an additional $5 \mathrm{~min}$ in the same manner. The aqueous and organic partitions were separated by centrifuge for $15 \mathrm{~min}$ (Savant speed vac, svc 200). The organic layer was removed using a Pasteur pipette and evaporated under a stream of $\mathrm{N}_{2}$, leaving the organic soluble material to be dissolved in $0.8 \mathrm{~mL}$ of methanol and analyzed by high-performance liquid chromatography (HPLC).

Podophyllotoxin in the purified extract was analyzed using an HPLC system (Agilent 1200 series consisting of a vacuum degasser, quaternary pump, ALS autosampler, a photodiode array detector, and an Agilent Eclipse XDB-C18, $4.6 \times 150 \mathrm{~mm}, 5-\mu \mathrm{m}$ column). The injection volume for all samples and for the podophyllotoxin standard was $10 \mu \mathrm{L}$ and standards and samples were analyzed at room temperature. The analytical method was isocratic ( $28 \%$ acetonitrile: $72 \%$ deionized water containing $0.1 \%$ trifluoroacetic acid) for $20 \mathrm{~min}$ followed by a 5 -min column wash with methanol and re-equilibration. 
Table 1. Mean Podophyllotoxin concentration (\%) from the 20 Juniperus accessions, ${ }^{\mathrm{z}}$ elevation, and GPS coordinates of each collection site.

\begin{tabular}{|c|c|c|c|}
\hline Accession no., species & $\begin{array}{c}\text { Podophyllotoxin } \\
(\%)\end{array}$ & $\begin{array}{l}\text { Elevation } \\
\text { (m) }\end{array}$ & GPS coordinates \\
\hline 130, J. scopulorum Sarg. & $0.156 \mathrm{~h}$ & 2072 & Lat. $\mathrm{N} 44^{\circ} 37.077^{\prime}$, long. $\mathrm{W} 107^{\circ} 05.166$ \\
\hline 131, J. horizontalis Moench & $0.457 \mathrm{~d}$ & 2070 & Lat. $\mathrm{N} 44^{\circ} 37.108^{\prime}$, long. W $107^{\circ} 05.072^{\prime}$ \\
\hline 132, J. horizontalis Moench & $0.478 \mathrm{~cd}$ & 2049 & Lat. N $44^{\circ} 37.097^{\prime}$, long. W $107^{\circ} 04.925^{\prime}$ \\
\hline 133, J. horizontalis Moench & $0.312 \mathrm{e}$ & 1990 & Lat. $\mathrm{N} 44^{\circ} 37.056^{\prime}$, long. W $107^{\circ} 04.063^{\prime}$ \\
\hline $134, J$. horizontalis Moench & $0.531 \mathrm{bcd}$ & 1978 & Lat. N $44^{\circ} 37.041^{\prime}$, long. W $107^{\circ} 04.685^{\prime}$ \\
\hline 135, J. horizontalis Moench & $0.327 \mathrm{e}$ & 1948 & Lat. $\mathrm{N} 44^{\circ} 37.004^{\prime}$, long. W $107^{\circ} 04.666^{\prime}$ \\
\hline 136, J. horizontalis Moench & $\mathrm{h}$ & 1945 & Lat. $\mathrm{N} 44^{\circ} 37.006^{\prime}$, long. W $107^{\circ} 04.676^{\prime}$ \\
\hline $137, J$. horizontalis Moench & $0.151 \mathrm{~h}$ & 1942 & Lat. $\mathrm{N} 44^{\circ} 36.998^{\prime}$, long. W $107^{\circ} 04.679^{\prime}$ \\
\hline 138, J. scopulorum Sarg. & & 1909 & Lat. N $44^{\circ} 37.504^{\prime}$, long. W $107^{\circ} 05.323^{\prime}$ \\
\hline $139, J$. horizontalis Moench & $0.067 \mathrm{ij}$ & 1899 & Lat. N $44^{\circ} 37.497^{\prime}$, long. W $107^{\circ} 05.287^{\prime}$ \\
\hline 140, J. horizontalis Moench & 0.287 ef & 1893 & Lat. $\mathrm{N} 44^{\circ} 37.495^{\prime}$, long. $\mathrm{W} 107^{\circ} 05.274^{\prime}$ \\
\hline 141, J. scopulorum Sarg. & $5 \mathrm{~h}$ & 1888 & Lat. $\mathrm{N} 44^{\circ} 37.484^{\prime}$, long. $\mathrm{W} 107^{\circ} 05.280^{\prime}$ \\
\hline $142, J$. horizontalis Moench & $0.253 \mathrm{efg}$ & 1839 & Lat. $\mathrm{N} 44^{\circ} 37.440^{\prime}$, long. $\mathrm{W} 107^{\circ} 05.246^{\prime}$ \\
\hline $2-117 \mathrm{~N}, J$. horizontalis Moench & $0.058 \mathrm{j}$ & 1793 & Lat. $\mathrm{N} 44^{\circ} 37.493^{\prime}$, long. W $107^{\circ} 05.134^{\prime}$ \\
\hline 2-117O, J. horizontalis Moench & $0.565 \mathrm{~b}$ & 1814 & Lat. $\mathrm{N} 44^{\circ} 37.517^{\prime}$, long. W $107^{\circ} 05.152^{\prime}$ \\
\hline $2-118 \mathrm{~N}, J$. horizontalis Moench & $0.555 \mathrm{bc}$ & 1961 & Lat. $\mathrm{N} 44^{\circ} 37.033^{\prime}$, long. $\mathrm{W} 107^{\circ} 04.660^{\prime}$ \\
\hline 2-1180, J. horizontalis Moench & $0.673 \mathrm{a}$ & 1961 & Lat. $\mathrm{N} 44^{\circ} 37.033^{\prime}$, long. W $107^{\circ} 04.660^{\prime}$ \\
\hline 2-118P, J. horizontalis Moench & $0.138 \mathrm{hi}$ & 1961 & Lat. $\mathrm{N} 44^{\circ} 37.033^{\prime}$, long. $\mathrm{W} 107^{\circ} 04.660^{\prime}$ \\
\hline I horizontalis M & $0.215 \mathrm{fgh}$ & 1963 & Lat. $\mathrm{N} 44^{\circ} 37.032^{\prime}$, long. $\mathrm{W} 107^{\circ} 04.670^{\prime}$ \\
\hline 2-118R, J. horizontalis Moench & $0.202 \mathrm{gh}$ & 1970 & Lat. $\mathrm{N} 44^{\circ} 37.037^{\prime}$, long. W $107^{\circ} 04.675^{\prime}$ \\
\hline
\end{tabular}

${ }^{2}$ Means sharing the same letter are not significantly different at the $5 \%$ level.

Analytes were detected at $220 \mathrm{~nm}$ with a reference of $450 \mathrm{~nm}$ by a photodiode array detector.

Quantitation was performed by means of an external standard calibration curve obtained from standard solutions of pure podophyllotoxin, purchased from Sigma-Aldrich (St. Louis, MO). Linearity was imposed by using response factors and regression coefficients independently. Response factors (RFs) were calculated using the equation $R F=D R / C$, where DR was the detector response in peak area (PA) and $\mathrm{C}$ was the analyte concentration. The target podophyllotoxin peak was confirmed by retention time and ultraviolet spectroscopy from 200 to $500 \mathrm{~nm}$. The RF of the target chemical constituent was used to determine the percent for each sample using the equation: $(\mathrm{PA} / \mathrm{RF} / \mathrm{C}) * 100=\%$.

Statistical analysis. The effect of $20 \mathrm{ju}-$ niper tree accessions on podophyllotoxin (\%) was determined by conducting a one-way analysis of variance (ANOVA) using the GLM procedure of SAS (SAS Institute Inc., 2008). The validity of the ANOVA model assumptions, namely normal distribution and constant variance assumptions on the error terms, was verified by examining the residuals as described in Montgomery (2009). Because the effect of accession was highly significant $(P<0.01)$, further multiple means comparison was done using Tukey's honestly significant difference method at the 5\% level. The more conservative Tukey's method was used because of the low experimental error and to protect the Type I experimentwise error rate from overinflation resulting from the relatively large number of accessions.

\section{Results and Discussion}

As expected, podophyllotoxin concentration in the collected samples varied in wide ranges from $0.058 \%$ to $0.673 \%$ (Table 1 ). Five accessions had podophyllotoxin concentration above $0.5 \%$, two accessions had a podophyllotoxin concentration between $0.45 \%$ and $0.5 \%$, two accessions had a podophyllotoxin concentration between $0.3 \%$ and $0.4 \%$, four accessions had a podophyllotoxin concentration between $0.2 \%$ and $0.3 \%$, five accessions had a podophyllotoxin concentration between $0.1 \%$ and $0.2 \%$, and two accessions had a podophyllotoxin concentration between $0.05 \%$ and $0.1 \%$.

In this study, we found seven accessions of creeping juniper with podophyllotoxin concentrations above $0.5 \%$. Previously, Cantrell et al. (2013) reported $0.254 \%$ and $0.138 \%$ podophyllotoxin in two accessions of creeping juniper ( $J$. horizontalis). In a recent study in a wider range of the Big Horn Mountains, Zheljazkov et al. (2013) found podophyllotoxin concentration range of $0.27-0.073 \%$ in $J$. horizontalis, $0-0.40 \%$ in $J$. scopulorum, and none in $J$. communis.

Previous research on Eastern red cedar found podophylloxin concentration to be between $0.1 \%$ and $0.34 \%$ (Gawde et al., 2009) and $0.1 \%$ to $0.18 \%$ (Cushman et al., 2003). However, Cantrell et al. (2013) in a recent study reported $0.48 \%, 0.044 \%, 0.28 \%$, and $0.66 \%$ in four different accessions of $J$. virginiana.

Apparently, the range of podophyllotoxin concentrations in creeping juniper in the Big Horn Mountains in this study was either higher or similar to the ones reported for Eastern red cedar. Hence, creeping juniper accessions found in the Big Horn Mountains seem promising as a source for podophyllotoxin.

\section{Literature Cited}

Bogdanova, V.P. and V.S. Sokolov. 1973. Developmental features of Podophyllum peltatum L. and Podophyllum emodii Wall. in cultivation conditions in the Lvov province. Herba Polonica. 19:379-384.

Canel, C., F.E. Dayan, M. Ganzera, I.A. Khan, A. Rimando, C.L. Burandt, Jr., and R.M. Moraes. 2001. High yield of podophyllotoxin from leaves of Podophyllum peltatum by in situ conversion of podophyllotoxin 4-O- $\beta$-Dglucopyranoside. Planta Med. 67:97-99.
Cantrell, C.L., V.D. Zheljazkov, W.A. Osbrink, A. Castro-Ruiz, V. Maddox, L.E. Craker, and T. Astatkie. 2013. Podophyllotoxin and essential oil profile of juniperus and related species. Ind. Crops Prod. 43:668-676.

Cushman, K.E., M. Maqbool, and P.D. Gerard. 2005. Mulch type, mulch depth, and rhizome planting depth for field-grown American mayapple. HortScience 40:635-639.

Cushman, K.E., M. Maqbool, P.D. Gerard, E Bedir, H. Lata, and R.M. Moraes. 2003. Variation of podophyllotoxin in leaves of Eastern red cedar (Juniperus virginiana). Planta Med. 69:477-478.

Gawde, A.J., V.D. Zheljazkov, V. Maddox, and C.L. Cantrell. 2009. Bioprospection of Eastern red cedar from nine physiographic regions in Mississippi. Ind. Crops Prod. 30:59-64.

Hammonds, T.R., S.P. Denyer, D.E. Jackson, and W.L. Irving. 1996. Studies to show that with podophyllotoxin the early replicative stages of herpes virus type 1 depend upon functional cytoplasmic microtubules. J. Med. Microbiol. 45:167-172.

Hartwell, J.L., J.M. Johnson, D.B. Fitzgerald, and M. Belkin. 1953. Podophyllotoxin from Juniperus species. Savinin. J. Amer. Chem. Soc. 75:235-236

Imbert, F. 1998. Discovery of podophyllotoxins. Biochimie 80:207-222

Koulman, A., W.J. Quax, and N. Pras. 2004 Biotechnology of medicinal plants: Vitalizer and therapeutic: Podophyllotoxin and related lignans produced by plants. In: Ramawat, K.G. (ed.). Science Publishers, Enfield, NH.

Leander, K. and B. Rosen. 1988. Medicinal used for podophyllotoxin. US patent 4,788,216.

Lerndal, T. and B. Svensson. 2000. A clinical study of $\mathrm{CPH} 82$ vs. methotrexate in early rheumatoid arthritis. Rheumatology (Oxford) 39: 316-320.

Meijer, W. 1974. Podophyllum peltatum-Mayapple: A potential new cash crop plant of eastern North America. Econ. Bot. 28:68-72.

Montgomery, D.C. 2009. Design and analysis of experiments. $7^{\text {th }}$ Ed. Wiley, New York, NY.

Moraes, R.M., H. Lata, E. Bedir, M. Maqbool, and K. Cushman. 2002. The American mayapple and its potential for podophyllotoxin production, p. 527-532. In: Trends in new crops and new uses. Proc. of the Fifth National Symposium, Atlanta, Georgia, USA, 10-13 Nov. 2001. ASHS Press, Alexandria, VA.

Renouard, S., T. Lopez, O. Hendrawati, P. Dupre, J. Doussot, A. Falguieres, C. Ferroud, D. Hagege, F. Lamblin, E. Laine, and C. Hano. 2011. Podophyllotoxin and deoxypodophyllotoxin in Juniperus bermudiana and 12 other Juniperus species: Optimization of extraction, method validation, and quantification. J. Agr. Food Chem. 59:8101-8107.

Saraeva, P.I. 1952. Mayapple, p. 273-274. In: Saraeva, P.I. (ed.). Medicinal plants and their cultivation. Medgiz, Moscow, Russia.

SAS Institute Inc. 2008. SAS/STAT ${ }^{\circledR} 9.2$ user's guide. SAS Institute Inc., Cary, NC.

Stahelin, H.F. and A.V. Wartburg. 1991. The chemical and biological route from podophyllotoxin to etoposide. Cancer Res. 51:5-15.

Zheljazkov, V.D., B. Avula, A.M. Jones, V. Maddox, and D.E. Rowe. 2009. Lignan and nutrient concentrations in American Mayapple (Podophyllum peltatum L.) in the eastern United States. HortScience 44:349-353.

Zheljazkov, V.D., C.L. Cantrell, M.A. Donega, and T. Astatkie. 2013. Bioprospecting for podophyllotoxin in the Big Horn Mountains, Wyoming. Ind. Crop Prod. 43:787-790. 